\title{
Correction to: A noninvasive model to predict liver histology for antiviral therapy decision in chronic hepatitis B with alanine aminotransferase $<2$ upper limit of normal
}

Shanshan Chen ${ }^{1,2}$, Haijun Huang ${ }^{1 *}$ and Wei Huang ${ }^{3}$

\section{Correction to: BMC Gastroenterol (2021) 21:4}

https://doi.org/10.1186/s12876-020-01576-6

Following publication of the original article [1], the authors identified incorrect corresponding author mentioned. Correct corresponding author is Haijun Huang.

\section{Author details}

${ }^{1}$ Department of Infectious Disease, Zhejiang Provincial People's Hospital, Hangzhou 310014, Zhejiang, China. ${ }^{2}$ Graduate School of Clinical Medicine, Bengbu Medical College, Bengbu 233000, Anhui, China. ${ }^{3}$ Department of Digestive Disease, Zhejiang Provincial People's Hospital, Hangzhou 310014, Zhejiang, China.

Published online: 05 March 2021

\section{Reference}

1. Chen $\mathrm{S}$, et al. A noninvasive model to predict liver histology for antiviral therapy decision in chronic hepatitis B with alanine aminotransferase < 2 upper limit of normal. BMC Gastroenterol. 2021;21:4. https://doi. org/10.1186/s12876-020-01576-6.

\section{Publisher's Note}

Springer Nature remains neutral with regard to jurisdictional claims in published maps and institutional affiliations. regulation or exceeds the permitted use, you will need to obtain permission directly from the copyright holder. To view a copy of this licence, visit http://creativecommons.org/licenses/by/4.0/. The Creative Commons Public Domain Dedication waiver (http://creativeco mmons.org/publicdomain/zero/1.0/) applies to the data made available in this article, unless otherwise stated in a credit line to the data. 